\title{
Ekologiczne samookreślenia Jezusa w Ewangelii wg św. Jana
}

Autor czwartej Ewangelii ${ }^{1}$ pod koniec swojego dzieła wskazuje na jego zasadniczy cel: „wiele innych znaków, których nie zapisano w tej książce, uczynił Jezus wobec uczniów. \e zaś zapisano, abyście wierzyli, że Jezus jest Mesjaszem, Synem Bożym, i abyście wierząc mieli życie w imię Jego" (J 20,30-31)². Przypominając główne tematy teologiczne ewangelista stwierdza tutaj, że napisał tę Ewangelię po to, aby czytelnicy uwierzyli, że to właśnie Jezus jest zapowiedzianym przez proroków Mesjaszem, Synem Bożym, a także zapewnia, że wiara w Jezusa daje życie wieczne ${ }^{3}$. Nie dziwi więc fakt, że sam Jezus w relacji Ewangelii wg św. Jana - podobnie jak w ewangeliach synoptycznych - nie tylko wędruje "nauczając i głosząc Ewangelię o królestwie Bożym" (Łk 8,1) oraz czyni spektakularne cuda4, lecz także w licznych dialogach i monologach dużo mówi o tym, kim jest i jaką misję ma do spełnienia.

Jezus ukazany na kartach Ewangelii wg św. Jana odwołuje się często do obrazów. Przede wszystkim w swoich mowach posługuje się On metaforami, parabolami, symbolami i słowami wieloznacznymi ${ }^{5}$. Jezus wykorzystuje przy tym różne motywy i przedstawienia z świata roślin, zwierząt oraz ludzi, aby być zrozumiałym dla swoich słuchaczy, aby ich przekonać i aby wywrzeć na nich wrażenie ${ }^{6}$. Zwłaszcza wtedy, gdy pragnie wyrazić trudne prawdy o swojej godności i posłan-

\footnotetext{
W kwestii autorstwa Ewangelii wg św. Jana por. A. PACIOREK, Ewangelia umilowanego ucznia, Lublin 2000, 35-57.

2 O celu napisania czwartej Ewangelii por. np. A. PAcIorek, dz. cyt. 99-113; M. Bednarz, Pisma św. Jana (Academica 18), \arnów ${ }^{4} 2000,36-39$.

Por. M. Bednarz, dz. cyt. 37.

4 W Ewangelii wg św. Jana mowa jest tylko o siedmiu cudach Jezusa.

5 O specyficznym języku Ewangelii Janowej por. S. Mędala, Chwała Jezusa (Ewangelia wg św. Jana), w: J. FrankowsKi - R. BARTNICKI (red.), Wprowadzenie w myśl i wezwanie ksigg biblijnych. 10. Ewangelia wgśw. Jana. Listy Powszechne. Apokalipsa, Warszawa 1992, 13-59, 18-21.

6 Por. C.G. Müller, Gottes Pflanzung - Gottes Bau-Gottes Tempel. Die metaphorische Dimension paulinischer Gemeindetheologie in 1Kor 3,5-17 (FuSt 5), Frankfurt/M. 1995, 41-44.
} 
nictwie, ucieka się chętnie do dobrze znanych swoim odbiorcom „pól obrazów” z dziedziny ekologii.

\section{Jezus w Ewangelii wg św. Jana}

Ewangelista Jan pogłębia i ubogaca obraz Jezusa znany z ewangelii synoptycznych. Kreśli on niejako duchowy portret Jezusa Chrystusa, który ,jest objawicielem, ostatnim i definitywnym słowem Boga skierowanym do ludzkości”". W pierwszej części Ewangelii objawia się Jezus światu poprzez swoje mesjańskie znaki i mowy (J 1-12), a potem objawia się swoim uczniom w tzw. „mowach pożegnalnych" (J 13-17) oraz poprzez swoją mękę, śmierć i zmartwychwstanie (J $18-20)^{9}$.

W całej Ewangelii Janowej przewijają się wypowiedzi Jezusa, w których mówi On o swojej relacji do Boga Ojca, wskazując przy tym nie tylko na swoje synostwo, lecz także na swoją jedność i równość z Ojcem ${ }^{10}$, którą określić można jako osobową wspólnotę życia i miłości z Ojcem ${ }^{11}$. Wystarczy tu przypomnieć takie słowa Jezusa, jak: „Ja i Ojciec jedno jesteśmy” (10,30), czy też prośby kierowane do Ojca w modlitwie arcykapłańskiej (J 17): „Ojcze Święty, zachowaj ich w \woim imieniu, które Mi dałeś, aby tak jak My stanowili jedno” $(17,11)$, „aby wszyscy stanowili jedno, jak 『y, Ojcze, we Mnie, a Ja w \obie, aby i oni stanowili w Nas jedno, aby świat uwierzył, żeś छy Mnie posłał" (17,21), „także chwałę, którą Mi dałeś, przekazałem im, aby stanowili jedno, tak jak My jedno stanowimy" (J 17,22). Do słuchających Go ludzi powie Jezus: „Moim pokarmem jest wypełnić wolę \ego, który Mnie posłał, i wykonać Jego dzieło" $(4,34)$, a w mowie eu-

Pod pojęciem „pola obrazu“ należy rozumieć zgrupowania metafor, które występują często w grupach i w łączności z innymi metaforami. \ak C.G. Müller, dz. cyt. 30. H. Weinrich, Sprache in Texten, Stuttgart 1976, 283 uważa, że tak jak pojedynczy wyraz w języku nie ma oddzielnej egzystencji, tak też pojedyncza metafora należy do pola obrazu; ona jest „miejscem w polu obrazu". D. PEIL, Untersuchungen zur Staats- und Herrschaftsmetaphorik in literarischen Zeugnissen von der Antike bis zur Gegenwart, München 1983, 24 jako „pole obrazu“ rozumie strukturę, która składa się z różnych elementów obrazu i istniejących między nimi relacji. Zarówno elementy, jak i relacje mogą zmieniać się ze względu na ich liczbę i zabarwienie, tak że możliwe są różne warianty i odcienie obrazów. Por. też R. Zimmermann, Die Gleichnisse Jesu, w: 囚enże (red.), Kompendium der Gleichnisse Jesu, Gütersloh 2007, 3-46, 39-41.

P

${ }^{11}$ Por. J. Zmijewski, Gott, Jesu Vater und unser Vater nach dem Zeugnis der Evangelien, w: B. Willmes - J. ZMiJeWSKI - K. Diez, Gott als Vater in Bibel und Liturgie (FHS 34), Frankfurt am Main, 2000, 59-88, 62 . 
charystycznej: „z nieba zstąpiłem nie po to, aby pełnić swoją wolę, ale wolę \ego, który Mnie posłał" $(6,38)$. Proszącemu o pokazanie uczniom Ojca Filipowi odpowie: „Filipie, tak długo jestem $z$ wami, a jeszcze Mnie nie poznałeś? Kto Mnie zobaczył, zobaczył także i Ojca" (J 14,9). Nikodem pozdrowi zaś Jezusa słowami: „Rabbi, wiemy, że od Boga przyszedłeś jako nauczyciel. Nikt bowiem nie mógłby czynić takich znaków, jakie \y czynisz, gdyby Bóg nie był z Nim" $(3,2)$, a Piotr wyzna: „myśmy uwierzyli i poznali, że Đy jesteś Świętym Boga” $(6,69)^{12}$. Oprócz tego Jezus określany jest w Ewangelii takimi tytułami, jak: Logos $(1,1.14)$, Syn Boży $(3,18 ; 5,25 ; 11,4.27)$, Syn Człowieczy $(1,51 ; 3,13 ; 6,27.62 ; 8,28 ; 12,23.34)$, Mesjasz $(1,41 ; 7,27.31 .41 ; 9,22 ; 11,27 ; 12,34)$, Baranek Boży $(1,29.36)^{13}$.

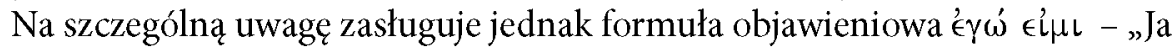

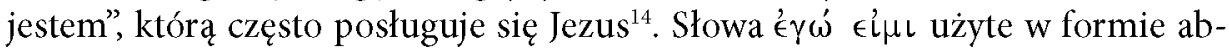
solutnej, tzn. bez żadnych dodatków, przypominają teksty Starego \estamentu, w których Bóg objawia się człowiekowi. W Rdz 28,13 przemawia Bóg do Jakuba we śnie: „Ja jestem Pan, Bóg Abrahama i Bóg Izaaka”, a przebywający w Egipcie Mojżesz, który pyta Boga, jakie jest Jego imię, usłyszy: „Jestem, który jestem” (Wj 3,14). W Starym \estamencie Bóg mówiąc „Ja jestem" nie tylko objawia człowiekowi swoją istotę ( $\mathrm{Rdz} 28,13$; Wj 3,14; 6,2.29; Ez 20,5; Ps 81,11 i in.), lecz także uzasadnia i potwierdza swoje słowa (Wj 20,1.5; Kpł 17-26), przekazuje treść objawienia oraz podkreśla, że jest On Bogiem Jednym i Jedynym ${ }^{15}$. W powołaniach zaś starotestamentalnych proroków imię Boga Jahwe wskazywało również na Jego obecność, opiekę i troskę o powołanego (por. Jr 1,8.19; 15,20; 30,11) ${ }^{16}$.

Jezus wypowiadając słowa '́ $\gamma \dot{\omega} \in \epsilon^{\prime} \iota \mu \iota$ objawia swoją godność Syna Bożego i daje wszystkim do zrozumienia, „że Bóg poprzez Niego jest obecny wśród ludzi”"17. Czas teraźniejszy tych słów (por. J 8,58: „Zanim Abraham stał się, Ja Jestem”) ujawnia także preegzystencję Jezusa oraz ponadczasowość i trwałość Jego czasów ${ }^{18}$. Jezus posługu-

12 Por. J. DrGas, „Kto mnie zobaczyl, zobaczyt także i Ojca” (J 14,9). Bóg Ojciec w Ewangelii Janowej, w: F. Mickiewicz - J. Warzecha (red.), Ty, Panie jesteś naszym Ojcem (Iz 64,7). Biblia o Bogu Ojcu (Rozprawy i Studia Biblijne 5), Warszawa 1999, 114-124.

13 Por. np. K.H. Schelkle, \eologia Nowego 冈estamentu. II: Bóg był w Chrystusie, Kraków 1985, 194-239; A. Paciorek, Ewangelia umiłowanego ucznia 194-235; S. Gądecki, Wstęp do pism Janowych, Gniezno 1991, 39-45.

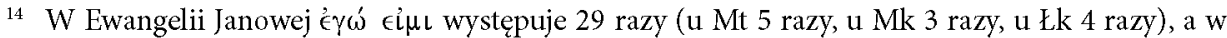
ustach Jezusa 26 razy (u Mt 1 raz, u Mk 2 razy, u Łk 2 razy). Dokładnie na ten temat Exkurs pt. „Herkunft und Sinn der Fromel $\epsilon \gamma \omega \dot{\epsilon} \epsilon \jmath \iota \mathrm{w}$ : R. Schnackenburg, Das Johannesevangelium. Zweiter 冈eil: Kommentar zu Kapitel 5- 12 (HThK IV/2), Freiburg - Basel - Wien ${ }^{5}$ 1990, 59-70.

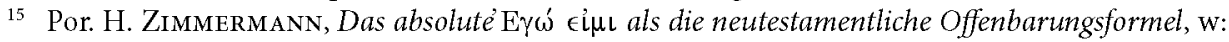
Biblische Zeitschrift. Neue Folge 4(1960), 54-69, 62-64.

16 Por. A.J. NaJDA, Der Apostel als Prophet. Zur prophetischen Dimension des paulinischen Apostolats (EHS XXIII/784), Frankfurt am Main - Berlin - Bern - Bruxelles - New York - Oxford - Wien 2004, 74-76.

17 H. LangKammer, Wprowadzenie do ksigg Nowego Testamentu, Wrocław 1992, 402.

18 Por. R. Schnackenburg, dz. cyt. 300n. 


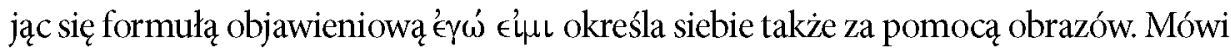
bowiem o sobie, że jest „chlebem życia” (6,35.48; por. 6,51: „chleb żywy”; 6,41: „chleb, który z nieba zstąpil”), „światłością świata” (8,12; por. 9,5), „bramą owiec” $(10,7.9)$, „dobrym pasterzem” (10,11.14), „zmartwychwstaniem i życiem” $(11,25)$, „drogą, prawdą i życiem" $(14,6)$ i „prawdziwym krzewem winnym" $(15,1.5)$. Obrazy te, występujące już w Starym 区estamencie i w literaturze judaistycznej, posiadaly utrwalone znaczenie symboliczne i teologiczne ${ }^{19}$. Świadomie sięga do nich Jezus, odnosi je do swojej Osoby i swego posłannictwa nadając im nową treść. Warto zauważyć, że spośród siedmiu ${ }^{20}$ wymienionych „pól obrazów”, aż cztery pochodzą z dziedziny ekologii, tak bliskiej i dobrze znanej ówczesnym słuchaczom lub czytelnikom.

\section{Jezus światłością świata}

Jezus wiedząc, że Żydzi w Judei zamierzali Go zabić, pozostawał w Galilei. Nie od razu też przybył do Jerozolimy na Święto Namiotów (J 7,1n). Święto to, zwane po hebrajsku "Sukkot", które obchodzono przez siedem dni na przełomie września i października ${ }^{21}$, było dziękczynieniem za zebrane plony zbóż i owoców, a także błaganiem o deszcz. Po niewoli babilońskiej, to jest od VI w. p. Chr., ze świętem tym związana była pielgrzymka do Świątyni Jerozolimskiej. Święto Namiotów upamiętniało wyjście Narodu Wybranego z ziemi egipskiej oraz wędrówkę przez pustynię, podczas której Bóg go prowadził i otaczał swoją szczególną opieką. Aby przypomnieć namioty, w których mieszkali Izraelici na pustyni (por. Ne 8,13-17), na czas Święta Namiotów budowano szałasy z gałęzi i liści, w których spożywano posiłki i niekiedy, gdy pozwalała na to pogoda, także nocowano ${ }^{22}$.

Pan Jezus przybył do Jerozolimy „dopiero w połowie świąt" (J 7,14) i tam nauczał w świątyni. Ludzie różnie reagowali na Jego słowa. Żydzi dziwili się skąd zna On Pisma, „skoro się nie uczy” (J 7,15); niektórzy mieszkańcy Jerozolimy powątpiewali o Jego mesjańskiej godności (J 7,25-27), a „wielu spośród tłumu uwierzyło w Niego" (J 7,31). Kapłani zaś z faryzeuszami „wysłali straż, aby Go pojmać" (J 7,32). W ostatnim dniu Święta Namiotów Chrystus stojąc zawołał donośnym głosem: „Jeśli ktoś jest spragniony, a wierzy we Mnie - niech przyjdzie do Mnie i pije! Jak rzekło Pismo: Strumienie wody żywej popłyną z jego wnętrza" (J 7,37-38). Jezus nawiązał tu do kulminacyjnego momentu obchodów,

\footnotetext{
\amże 60n. Por. też J. Gnilka, Teologia Nowego Testamentu, Kraków 2002, 319n.

20 O symbolice liczby siedem por. M. LuRker, Stownik obrazów i symboli biblijnych, Poznan 1989, $212 \mathrm{n}$.

21 W hebrajskim kalendarzu było to dokładnie od 15 do 21 dnia miesiąca tiszri. Na diasporze obchodzono to święto osiem dni.

22 Por. B.A. Levine, Święta i uroczystości, w: B.M. Metzger - M.D. Coogan (red.), Stownik wiedzy biblijnej, Warszawa 1996, 749-752, 751.
} 
kiedy to kapłan czerpał wodę z sadzawki Siloe i w uroczystej procesji przynosił ją na wewnętrzny dziedziniec świątyni, a potem wylewał ją na ołtarz całopalenia, aby zapewnić obfite opady jesienne ${ }^{23}$. Chrystus zaprasza w ten sposób każdego człowieka, który chce mieć prawdziwe życie, aby przyszedł do Niego. Oświadcza też, „że jest w stanie ofiarować... coś więcej niż rytualną wodę"24. Jako Mesjasz spełni Jezus zapowiedziane przez starotestamentalnych proroków (por. Iz 43,20; 44,3; 58,11; Ez 47,1; Za 14,8) wylanie Ducha Świętego, którego symbolizuje żywa woda. Sam zaś Jezus jawi się jako „prawdziwe źródło wody żywej” ${ }^{25}$, nie ma tu jednak formuly objawieniowej $\epsilon^{\prime} \gamma \omega^{\prime} \in \dot{\epsilon} \mu \mathrm{L}$.

Po perykopie o kobiecie cudzołożnej (J 8,1-11) ${ }^{26}$ Jezus kontynuuje dyskusję ze swoimi słuchaczami, którą prowadził w uroczystej scenerii święta Namiotów. Podczas wieczornych uroczystości zapalano liczne lampy w świątyni na dziedzińcu kobiet (por. J 8,20), które miały przypominać słup ognia prowadzący Izraelitów w czasie wędrówki przez pustynię (por. Wj 13-21) ${ }^{27}$. Chrystus rozpoczyna od uroczystego stwierdzenia: „Ja jestem światłością świata. Kto idzie za Mną, nie będzie chodził w ciemności, lecz będzie miał światło życia" (J 8,12).

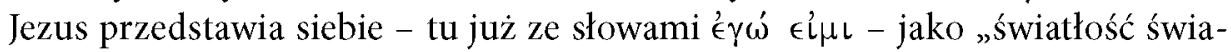

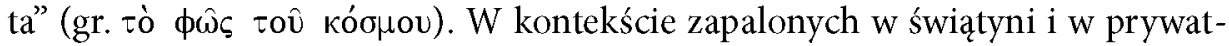
nych domach świateł podkreśla On, że jest kimś więcej niż światła rozświetlające i upiększające tej nocy Jerozolimę. Jezus jest eschatologicznym światłem, które przyszło na świat, aby całej ludzkości dać prawdziwe światło i życie. \akże słuchający Go ludzie są wezwani do wiary w Niego i do stania się „synami światłości" (J 12,36)

Wyrażenie „światłość świata” lub „lampa świata” było znane i wykorzystywane w judaizmie na określenie \ory, świątyni, Jerozolimy, Izraela, oraz takich osób, jak Adam czy nauczyciel 区ory, a także jako synonim samego Boga ${ }^{29}$. W Starym Destamencie wszelkie światło rozumiano jako dar Boga wyznaczający kierunek życia i zbawienia ludzi (Ps 36,10; por. Ps 80,4.8.20; 119,105). 凶o światło, które można znaleźć jedynie w Bogu, koncentruje się teraz w Jezusie, Synu Bożym. „Swiatłem jest przyniesione przez Jezusa $\mathbf{i}$ ofiarowane zbawienie”30. Kto jako uczeń Jezusa idzie za Nim, znajdzie na tej drodze kierunek życia i zbawienie

23 Por. C.S. KeEnER, Komentarz historyczno-kulturowy do Nowego Testamentu, Warszawa ${ }^{2} 2000,203$.

24 A. Paciorek, Ewangelia wedlug św. Jana 114.

25 R. SChNACKenburg, dz. cyt. 214.

26 Perykopa ta nie należała pierwotnie do Ewangelii Janowej, a została dopiero później do niej dodana. Por. U. Wickens, Das Evangelium nach Johannes (N囚D $4^{18}$ ), Göttingen ${ }^{2} 2000,138-140$.

27 Por. S. MęDala, dz. cyt. 40; A.J. OŁów, Symbolika światła w Piśmie świętym, Łomża 2004, 50n.

28 Por. R. Schnackenburg, dz. cyt. 240.

29 Dokładnie na ten temat O. SchwankL, Licht und Finsternis. Ein metaphorisches Paradigma in den johanneischen Schriften (HBS 5), Freiburg im Breisgau - Basel - Wien - Barcelona - Rom - New York 1995, 38-72.

30 A. PacioreK, Ewangelia wedlug św. Jana 119. 
- samego Jezusa, który jest obecnością Boga w świecie ${ }^{31}$. W uczniach naśladujących Jezusa realizuje się bowiem Boża wola zbawienia świata (J 3,16). Świat zaś bez Jezusa, czy też przeciw Niemu, pozostaje w ciemnościach, to znaczy bez nadziei, prawdy i rzeczywistego życia, które jest tylko w Bogu ${ }^{32}$. Ciemność bez znajomości światła mogłaby się wydawać czymś normalnym. Gdy jednak człowiek pozna światło, nie chce już przebywać w ciemności. Zarówno on, jak też cała przyroda, potrzebuje światła do właściwego funkcjonowania. Dopiero w świetle człowiek czuje się pewny i bezpieczny ${ }^{33}$. Jezus zna te naturalne potrzeby człowieka i wychodzi im naprzeciw. Odwołując się do sfery ekologii nazywa siebie nie tylko zwyczajnym światłem, lecz światłością świata, która rozprasza mroki ciemności. Co więcej, On obiecuje każdemu dać światło życia. Warunkiem zaś otrzymania tego światła jest żywa wiara w Jezusa Chrystusa ${ }^{34}$.

\section{Jezus bramą owiec}

Po opisie uzdrowienia niewidomego od urodzenia i toczących się wokól tego cudu dyskusjach oraz pytaniach faryzeuszów o Jezusa (J 9), w następnym rozdziale ewangelista pragnie odpowiedzieć na pytania, kim jest Jezus, oraz co znaczy Jego życie i nauka dla zbawienia ludzi? Autor zmienia też „pola obrazów”, po metaforyce światła i ciemności następują teraz motywy bramy, pasterza, owiec, złodzieja i rozbójnika, do których odwołuje się Jezus w swojej mowie pa-

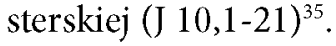

Zaskakiwać może fakt, że Jezus na początku swojej mowy posługuje się nie obrazem pasterza, lecz bramy. Odwołuje się On do dobrze znanych jego słuchaczom ówczesnych warunków przetrzymywania owiec. Istniały wspólne, otoczone murem zagrody, w których wielu posiadaczy mniejszych trzód trzymało swoje owce i zatrudniało do tego odźwiernego, który miał też czuwać nad trzodami. Gdy przychodził pasterz, odźwierny otwierał mu bramę, by ten wyprowadził swoje owce, wołając je po imieniu, co było powszechnym zwyczajem w basenie Morza Śródziemnego (por. J 10,2n) ${ }^{36}$. Kto wchodził inaczej niż przez bramę, ten był "złodziejem i rozbójnikiem”. Gdy natomiast owce były trzymane na pastwiskach z dala od domu, na noc wpędzano je na przygotowany w tym celu teren, ogrodzony kamieniami lub krzewami cierniowymi ${ }^{37}$. Jezus mówiąc o bramie

\footnotetext{
Por. U. Wilckens, dz. cyt. 140.

Damże.

33 Por. M. Lurker, dz. cyt. 237n.

34 Por. F. PoRsch, Johannes-Evangelium (SKK.N冈 4), Stuttgart 2003, 89.

35 Dokładnie na ten temat B. Kowalski, Die Hirtenrede im Kontent des Johannesevangeliums (Joh 10,1-18) (SBB 31), Stuttgart 1996.

36 Por. M. 凶heobald, Herrenworte im Johannesevangelium (HBS 34), Freiburg im Breisgau - Basel - Wien - Barcelona - Rom - New York 2002, 362.
} 
(J 10,1-5) ma na myśli to, że z jednej strony umożliwia ona pasterzowi dostęp do owiec, z drugiej zaś wchodzą i wychodzą przez nią owce ${ }^{38}$. Słuchacze nie rozumiejąc znaczenia tej „zagadki” (gr. $\pi \alpha \rho o \iota \mu i \alpha)^{39}$ Jezusa $(J 10,6)$ okazali się tymi, którzy nie należą do owiec Jezusa i nie znają Jego głosu ${ }^{40}$.

Jezus widząc reakcję słuchaczy powiedział do nich: „Zaprawdę, zaprawdę, powiadam wam: Ja jestem bramą owiec. Wszyscy, którzy przyszli przede Mną, są złodziejami i rozbójnikami, a nie posłuchały ich owce. Ja jestem bramą. Jeżeli ktoś wejdzie przeze Mnie, będzie zbawiony - wejdzie i wyjdzie, i znajdzie paszę. Złodziej przychodzi tylko po to, aby kraść, zabijać i niszczyć. Ja przyszedłem po to, aby owce mialy życie i miały je w obfitości" (J 10,7-10). Chrystus nazywa tu siebie „bramą owiec" i „bramą", używając dwa razy formuły objawieniowej

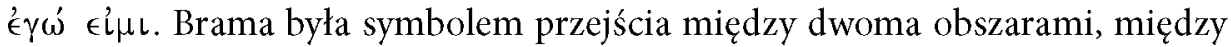
teraźniejszością a przeszłością, między świętością a laickością. W piramidach egipskich w przejściach między przedsionkami a pomieszczeniami z sarkofagami umieszczano inskrypcje o „wysokiej bramie”, którą nazywano „bramą wpustu”, to znaczy bramą do nieba ${ }^{41}$. W Biblii brama jest obrazem „miejsca przejścia między różnymi sferami istnienia” ${ }^{42}$. O „bramie nieba" bezpośrednio wspomina tylko Rdz 28,17 i Ps 78,23. Jezus mówiąc tu o bramie nie ma na myśli ciasnej (Łk 13,24) lub zamkniętej bramy (Łk 13,25), a raczej bramę, która raz przez Niego otwarta, przez nikogo nie może być zamknięta (por. Ap $3,7 n)^{43}$.

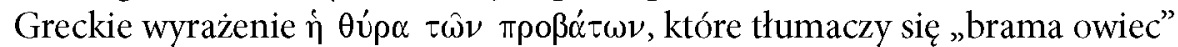
może oznaczać zarówno „bramę do owiec" jak i „bramę dla owiec”44. Jezus objawiając się jako „brama owiec” $(10,7)$, podkreśla swoje prawo wejścia do owczarni i bycia jej pasterzem. On jest jedynym dawcą i pośrednikiem zbawienia ${ }^{45}$. Brama jako symbol Zbawcy może posiadać także znaczenie mesjańskie z Ps 118,19-20: „Otwórzcie mi bramy sprawiedliwości: chcę wejść i złożyć dzięki Panu. Oto jest brama Pana, przez nią wejdą sprawiedliwi“46. W drugim samookreśleniu $(10,9)$ nie ma dodatku „owiec”. Jezus mówi tu o swoim zadaniu, jakie spełnia On jako

37 Por. B.J. Malina - R.L. Rohrbaugh, Social-Science Commentary on the Gospel of John, Augsburg 1998, 179.

38 Dak F. Porsch, dz. cyt. 109; A. PACIOREK, Ewangelia wedtug św. Jana 134.

39 Por. R. Popowski, Wielki slownikgrecko-polski Nowego Testamentu. Wydanie z pelna lokalizacja greckich hasel, kluczem grecko-polskim oraz indeksem form czasownikowych, Warszawa ${ }^{2} 1995,471$.

40 Por. R. Schnackenburg, dz. cyt. 358.

41 Por. M. Lurker, dz. cyt. 50.

42 冈ak B. ReIcKe, Art. \or, 囚ür 2, w: BHH III , 2010-2011.

43 Por. 冈. Popp, Die Tür ist offen. (Die 囚ür). Joh 10,7-10 (vgl. Agr 51), w: R. Zimmermann u.a. (red.), Kompendium der Gleichnisse Jesu, Gütersloh 2007, 781-787, 785.

${ }^{44}$ Por. R. Schnackenburg, dz. cyt. 363n.

45 \amże 366.

46 Por. A. Paciorek, Ewangelia wedtug św. Jana 134. 
brama dla uczniów. Jezus jest bramą, to znaczy jedynym miejscem, przez które owce przechodzą na pastwisko, czyli osiągają zbawienie ${ }^{47}$. Również tutaj obrazowym językiem z dziedziny ekologii, wykorzystując dobrze znane metafory bramy, owiec, pasterza i pastwisk, Chrystus wzywa słuchaczy do wiary w Niego, oraz wyjaśnia im, że tylko w Nim jest zbawienie i prawdziwe życie, które symbolicznie wyrażają pastwiska ${ }^{48}$.

\section{Jezus dobrym pasterzem}

W dalszej części swojej mowy pasterskiej (J 10,11-18) Jezus dwa razy (w w. 11 i 14) powie o sobie: "Ja jestem dobrym pasterzem", wypowiadając przy

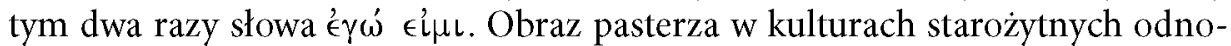
sił się do władców, którzy jako reprezentanci bogów byli ziemskimi pasterzami, a insygnium ich władzy był kij pasterski ${ }^{49}$. Zauważyć tam można zależność trzody od pasterza oraz władzę króla. Również w Starym \estamencie określano politycznych przywódców mianem pasterzy, począwszy od Dawida (2Sm 5,2; 7,7; 24,17), ale także ogólnie (1Krl 22,17; Jr 25,34-36; Iz 44,28; Za 11,3.4-17; Ps 78,70-72). Od czasów proroka Jeremiasza podkreślano także negatywne cechy pasterza. Podczas niewoli babilońskiej powstała idea owiec, które nie miały pasterza oraz rozumienie pasterzy jako słabych jednostek w porównaniu z mocą Boga ${ }^{50}$. Motyw pasterza odnoszono też $w$ czasie niewoli do oczekiwanych $w$ przyszłości postaci, które miały przynieść zbawienie i nadzieję (Jr 3,15; 23,4n; Mi 6,4; Ez 37,25). U proroka Ezechiela łączy się z tym zapowiedź królestwa pokoju (Ez 34,25-30) ${ }^{51}$.

Metafora pasterza przybiera szczególne znaczenie w odniesieniu do Boga. Bóstwa egipskie, babilońskie i irańskie nazywano pasterzami ${ }^{52}$. W Starym 冈estamencie metaforą pasterza określano Boga Jahwe. Boga przedstawiano jako pasterza (Ps 23,1; 80,2; Iz 40,11; Jr 31,9), a naród Izraela jako owce (Ps 74,1; 79,13; 95,7; 100,3 $)^{53}$. Bóg nazwany jest wprost pasterzem w Rdz 48,15; 49,24; Ps 23,1; 80,2 , porównany jest do pasterza w Iz 40,22; Syr 18,13, a jego działanie określone jako „pasanie” w Oz 4,16; Mi 7,14; Za 11,7.9; Ps 28,9. Poza tym istnieją liczne odniesienia do pasterskiego działania Boga (Iz 49,9-10; Jr 13,17; 23,3; 31,10; 50,17.19; Oz 13,5n; Mi 2,12; 4,6n; 7,14; So 3,19; Za 10,3; Ps 74,1; 77,21; 78,52;

47 Por. U. Wilckens, dz. cyt. 165.

48 Por. L. Rycken - J.C. Wilhoit - X. Longmann III, Słownik symboliki biblijnej, Warszawa 2003, $675 n$.

49 Por. R. Hunziker-Rodewald, Hirt und Herde. Ein Beitrag zum alttestamentlichen Gottesverständnis (BWAN囚 155), Stuttgart - Berlin - Köln 200, 34.

50 Por. B. Willmes, Die sogenannte Hirtenallegorie Ez 34. Studien zum Bild des Hirten im Alten 区estament (BEX 19), Frankfurt am Main - Bern - New York - Nancy 1984, 311-342.

51 Damże 342-351.

52 Por. B.J. Malina - R.L. Rohrbaugh, dz. cyt. 179.

53 W Iz 63,10 metafora pasterza odnosi się do Mojżesza. 
$79,13 ; 95,7 ; 100,3 ;$ Jdt 11,19$)^{54}$. Do zadań Jahwe jako pasterza należało prowadzenie ludu wybranego, troska o naród i o pojedynczego człowieka $a^{55}$.

Jezus nawiązując do tych funkcjonujących w świadomości słuchaczy wyobrażeń i treści nazywa siebie „dobrym pasterzem”. Charakteryzując dalej dobrego pasterza doda (J 10,11), że dobry pasterz oddaje swoje życie za owce. Owce są jego własnością, on nie opuszcza ich i nie ucieka na widok nadchodzącego wilka, tak jak czyni to najemnik $(10,12-13)$. Oddanie życia jest dobrowolnym czynem pasterza, który spełnia w ten sposób zadanie powierzone mu przez Ojca. Jezus ma moc oddać życie i ma moc znów je odzyskać $(10,18)$. Mówiąc o oddaniu życia za owce ma myśli rzeczywiste i dobrowolne oddanie życia, które jest wyrazem ofiarnej miłości pasterza ${ }^{56}$. Ponownie nazywając siebie „dobrym pasterzem” Jezus wyzna, że zna swoje owce, a jego owce Go znają, podobnie jak zna Go Ojciec, a On zna Ojca. Zaznacza przy tym, że z Jego owcami łączy go relacja wzajemnej znajomości, zaufania i miłości. Znać (gr. $\gamma(\nu \omega ́ \sigma \kappa \in \iota \nu$ ) nie oznacza tylko teoretycznego poznania, lecz więź osobową, poznanie prowadzące do głębokiej wspólnoty miłości, jaką Bóg obdarza swój lud i każdego człowieka ${ }^{57}$. Jak wielka jest miłość Jezusa do uczniów pokazuje porównanie do wzajemnego znania się Ojca i Syna. Większa miłość nie jest nawet do pomyślenia $^{58}$. Wyrazem tej nieskończonej miłości jest Jezusowa zapowiedź oddania życia za owce $(10,15)$. Słowa zaś o innych owcach, które pragnie przyprowadzić Jezus, dotyczą ludów pogańskich, ponieważ Jezus jest dobrym pasterzem, który gromadzi nie tylko rozproszone owce z Izraela, ale także ze wszystkich narodów $w^{59}$.

Jezus objawiając siebie jako „dobrego pasterza” nie tylko sięga do znanych ze Starego 冈estamentu „pól obrazów” odnoszących się do Boga, lecz także nawiązuje do ekologii ludzkiej. Przybliżając postać dobrego pasterza opisuje swoją relację nieskończonej miłości do ludzi i zapowiada wprost swoją ofiarę na drzewie krzyża za zbawienie wszystkich ludzi. Jego pragnieniem jest, aby powstała jedna owczarnia i jeden pasterz. Wszyscy uczniowie zaś „będą słuchać” Jego głosu $(10,16)$.

\section{Jezus prawdziwym krzewem winnym}

Po wezwaniu do wyjścia (J 14,31) kończącym pierwszą mowę pożegnalną (J 13,13-14,31) Jezus rozpoczyna swoją drugą mowę pożegnalną (J 15-16) ${ }^{60}$.

54 Por. B. Kowalski, Ruf in die Nachfolge. (Vom Hirt und den Schafen). Joh 10,1-5, w: R. ZimmermanN u.a. (red.), Kompendium der Gleichnisse Jesu, Gütersloh 2007,768-780, 777.

55 Por. B. Willmes, dz. cyt. 279-311.

56 Por. R. Schnackenburg, dz. cyt. 371 n.

57 Por. U. Wilckens, dz. cyt. 166.

58 Por. F. Porsch, dz. cyt. 111.

59 Por. A. PAciorek, Ewangelia według św. Jana 135.

60 Drugą mowę pożegnalną, którą kończy modlitwa arcykapłańska Jezusa (J 17), traktuje się jako późniejszy dodatek redaktora ewangelii. Nie umniejsza to w żadnym stopniu jej znaczenia. Mowę 
Wykorzystując motywy z pierwszej mowy pożegnalnej, w świetle zmienionej sytuacji, Zmartwychwstały i Uwielbiony Jezus dokonuje w drugiej mowie pożegnalnej aktualizacji i pogłębienia treści pierwszej mowy ${ }^{61}$. Chrystus podejmuje tu takie tematy, jak: zjednoczenie z Nim i jego owoce $(15,1-17)$, nienawiść świata i świadectwo Ducha $(15,18-16,15)$, powrót Jezusa, radość i wiara uczniów (16,16-33).

Jezus zaczyna jednak od mowy o winnym krzewie (J 15,1-8) ${ }^{62}$, w której dwa

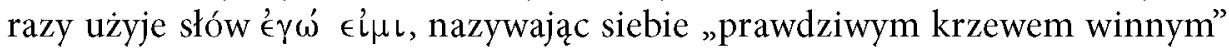
$(15,1)$ oraz „krzewem winnym" $(15,5)$. Posługuje się tu „polami obrazów” winnego krzewu z przynoszącymi owoce lub nie przynoszącymi owoców latoroślami oraz uprawiającego winnicę, który latorośle oczyszcza lub odcina i wrzuca w ogien' ${ }^{63}$. Obrazy te nawiązują od starotestamentalnych metaforycznych przedstawień Izraela jako winnicy Jahwe (Iz 5) lub krzewu winnego, zasadzonego i pielęgnowanego przez samego Boga, który daremnie oczekiwał na nim owoców (por. Jr 2,21; Ez 15; 17,1-10; 19,10-14; Mi 7,1; Oz 10,1; Ps 80, 9-17) ${ }^{64}$. Krzew nie przynosząc spodziewanych owoców, otrzymywał od uprawiającego winnicę nagany i zapowiedzi zniszczenia bądź sądu (por. Iz 5,5-30; 27,2-4; Jr 6,9; Ez 15,1-8) ${ }^{65}$. Były również pozytywne obrazy winnicy, zapowiadające odnowę Izraela i opiekę Boga, przede wszystkim w tzw. „Apokalipsie Izajasza” w Iz 2,2-4: „W ów dzień powiedzą: Winnica urocza! Śpiewajcie o niej! Ja, Pan, jestem jej stróżem; podlewam ją co chwila, by jej co złego nie spotkało, strzege jej w dzień i w nocy. Nie czuję gniewu. Niech Mi kto sprawi w niej ciernie i głogi! Wypowiem mu wojnę, spalę je wszystkie razem!“" (por. Oz 14,7; Jl 2,22). Zaś w Syr 24,17 upersonifikowana, postawiona na równi $\mathrm{z}$ 囚orą, mądrość sama porównuje się do winnego krzewu ${ }^{66}$.

tę należy rozumieć jako „relekturę” pierwszej. Por. A. DetTwiLer, Die Gegenwart des Erhöhten. Eine exegetische Studie zu den johanneischen Abschiedsreden (Joh 13,31-16,33) unter besonderer Berücksichtigung ihres Relecture-Charakters (FRLAN冈 168), Göttingen 1995, 44-52.

61 Por. J. Zumstein, Ein gewachsenes Evangelium. Der Relecture-Prozess bei Johannes, w: 冈. SöDING (red.), Johannesevangelium - Mitte oder Rand des Kanons? Neue Standortbestimmungen (QD 203), Freiburg - Basel - Wien 2003, 9-37, 24.

62 Mowę tę można podzielić na dwie części (J 15,1-4 i 15,5-8). Każda z tych części rozpoczyna się od słów Jezusa evgw, eivmi.

63 Por. U. Poplutz, Eine fruchtbare Allianz. (Weinstock, Winzer und Reben). Joh 15,1-8 (vgl. Agr 61), w: R. Zimmermann u.a. (red.), Kompendium der Gleichnisse Jesu, Gütersloh 2007, $828-839,830$.

64 Por. K. Scholtissek, In ihm sein und bleiben. Die Sprache der Immanenz in den johanneischen Schriften (HBS 21), Freiburg im Breisgau - Basel - Wien - Barcelona - Rom - New York 2000, 279 n.

65 Por. P. von Gemünden, Vegetationsmetaphorik im Neuen Testament und seiner Umwelt. Eine Bildfelduntersuchung (N囚OA 18), Freiburg - Göttingen 1993, 166.

66 Por. U. Poplutz, dz. cyt. $832 \mathrm{n}$. 
Jezus rozpoczyna swoją mowę od stwierdzenia, że jest On „prawdziwym win-

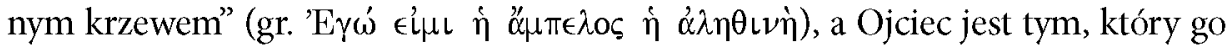
uprawia $(15,1)$. Wskazując na Ojca, który w zimie odcina uschłe gałązki, a wiosną oczyszcza latorośl, aby przynosiła owoc obfitszy, Jezus przedstawia się jako Syn,

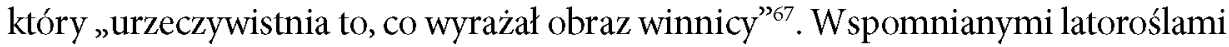
są uczniowie Jezusa ${ }^{68}$. Precyzyjne samookreślenie Jezusa „Ja jestem prawdziwym krzewem winnym" jest skierowane właśnie do uczniów, aby mieli świadomość, że oni - jako wierzący w Chrystusa - nie są winnym krzewem, lecz jedynie latorośla$\mathrm{mi}^{69}$. Zadaniem uczniów jest ciągłe stawianie sobie pytania, co mają czynić, aby nie zostać odciętymi od winnego krzewu? ${ }^{70} \mathrm{~W}$ kolejnym wersecie Jezus sam odpowiada na to pytanie opuszczając język metaforyczny i zwracając się do swoich uczniów: „Wy już jesteście czyści dzięki słowu, które wypowiedziałem do was. Wytrwajcie we Mnie, a Ja będę trwał w was" (15,3-4a). Chrystus przypomina tu swoim uczniom o otrzymanym już darze zbawienia oraz wzywa ich do trwania w stałej komunii $\mathrm{z} \mathrm{Nim}{ }^{71}$. Wezwanie to ilustruje znów ekologicznym obrazem winnego krzewu: „Podobnie jak latorośl nie może przynosić owocu sama z siebie - o ile nie trwa w winnym krzewie - tak samo i wy, jeżeli we Mnie trwać nie będziecie" $(15,4 b c)$.

W kolejnym zdaniu Jezus znów powie o sobie, że jest „winnym krzewem”, a swoich uczniów nazwie wprost latoroślami $(15,5)$. Rozwijając swoją myśl wyjaśni, że uczniowie wydadzą owoc tylko wtedy, gdy będą w Nim trwali, a On w nich. Bez Niego uczniowie nic nie mogą uczynić, to znaczy nie przyniosą żadnych owoców ${ }^{72}$. Każda latorośl, która nie trwa w winnym krzewie, usycha i zostaje spalona $(15,6)$. Dalej Jezus wzywając do wiary obiecuje, że kto będzie w Nim trwał, jak latorośl w winnym krzewie, ten otrzyma wszystko, o co będzie prosi ${ }^{73}$. W ostatnim zaś wersecie Chrystus podsumowując swoją mowę zaznaczy, że poprzez przynoszenie owoców, które świadczy o byciu Jego prawdziwym uczniem, dokonuje się uwielbienie Ojca ${ }^{74}$. Działanie Ojca - uprawiającego krzew winny i uczniów - latorośli „spotyka się" w zbieraniu owoców, a Jezus - winny krzew jest tym, który to umoźliwia i pośredniczy.

Podobnie jak we wcześniejszych tekstach, tak również tutaj Jezus objawia siebie i tłumaczy trudne prawdy o zbawieniu przy pomocy ekologicznych „pól ob-

67 A. PACIOREK, Ewangelia wedlug św. Jana 172.

68 Por. U. Wilckens, dz. cyt. 237.

69 Por. K. Haldimann, Rekonstruktion und Entfaltung. Exegetische Untersuchungen zu Joh 15 und 16 (BZNW 104), Berlin - New York 2000, 152-169.

70 Por. U. Poplutz, dz. cyt. 834.

71 Por. R. Schnackenburg, Das Johannesevangelium. Dritter Teil: Kornmentar zu Kapitel 13- 21 (HThK IV/3), Freiburg - Basel - Wien ${ }^{6} 1992,111 \mathrm{n}$.

72 Por. F. Porsch, dz. cyt. 165 n.

73 Por. J. Zumstein, dz. cyt. 148.

74 Por. U. Poplutz, dz. cyt. 836. 
razów". Ojciec czyni wszystko, aby zebrać jak największy owoc, uczniowie trwający w Jezusie przynoszą dobre owoce, Ojciec natomiast wysłuchuje ich modlitw, aby zabezpieczyć i zwiększyć owoce ${ }^{75}$.

\section{Znaczenie ekologii w objawieniu Jezusa}

Jezus zstąpił z nieba i stał się człowiekiem, aby dokonać dzieła zbawienia świata. $\mathrm{Na}$ kartach Ewangelii wg św. Jana wielokrotnie powie On, że został posłany przez Ojca, aby spełnić Jego wolę (por. J 6,38: „z nieba zstąpiłem nie po to, aby pełnić swoją wolę, ale wolę \ego, który Mnie posłał") ${ }^{76}$. W rozmowie z Nikodemem Chrystus wyjaśni, że „Bóg nie posłał swego Syna na świat po to, aby świat potępil, ale po to, by świat został przez Niego zbawiony" (J 3,17). Spełniając swoją misję zbawienia ludzkości Jezus objawia także siebie jako Syna Bożego ${ }^{77}$. Używa przy tym znanej ze Starego

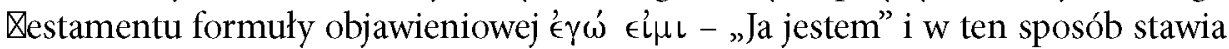
siebie na równi z Bogiem, co często wzbudza zgorszenie i sprzeciw słuchaczy (por. J 8,59). Mówiąc o tym, kim jest On dla swoich uczniów, którzy w Niego uwierzyli, Jezus posługuje się chętnie „polami obrazów” z dziedziny ekologii. Określa On siebie jako „światło świata” (J 8,12; por. 9,5), „brama owiec" (J 10,7.9), „dobry pasterz” (J 10,11.14) i „krzew winny” (J 15,1.5). Odwołując się do tych ekologicznych obrazów Jezus wzywa wszystkich ludzi do wiary w Niego jako Syna Bożego i zapowiadanego przez proroków Mesjasza. Wiara ta daje życie wieczne, bo Jezus przyszedł na świat „po to, aby owce miały życie i miały je w obfitości” (J 10,10).

\section{Ökologische Selbstbezeichnungen Jesu im Johannesevangelium}

\section{ZUSAMMENFASSUNG}

Jesus spricht oft im Johannesevangelium, er sei gekommen, den Willen des Vaters zu erfüllen (z.B. J 4,34, 6,38) und sich als den Sohn Gottes zu offenbaren. Wenn er die aus dem Alten \estament stammende Offenbarungsformel evgw, eivmi benutzt, dann stellt er sich als Gott vor. Um seine Sendung zu beschreiben, den Menschen das ewige Leben zu schenken, verwendet Jesus die Bildfelder aus der Ökologie, die von den Hörern recht gut bekannt und verstanden werden. Er bezeichnet sich nämlich als „das Licht der Welt“ (J 8,12), „die 囚ür“ (J 10,7.9), „der gute Hirt“ (J 10,11.14) und „der wahre Weinstock“ (J 15,1.5). Jesus tut es, um die Menschen zur Umkehr und zum Glauben zu bewegen, damit sie „das Leben haben und es in Fülle haben“ (J 10,10).

75 Por. R. Schnackenburg, Das Johannesevangelium III $115 \mathrm{n}$.

76 Por. J. GNilka, dz. cyt. 329-332.

77 Por. A. PAciorek, Ewangelia umiłowanego ucznia 220-229. 